\title{
ZMYND10 wt Allele
}

National Cancer Institute

\section{Source}

National Cancer Institute. ZMYND10 wt Allele. NCI Thesaurus. Code C111851.

Human ZMYND10 wild-type allele is located in the vicinity of 3p21.3 and is approximately $6 \mathrm{~kb}$ in length. This allele, which encodes zinc finger MYND domain-containing protein 10, is involved in motile ciliary function. Mutations in this gene are associated with primary ciliary dyskinesia-22. 